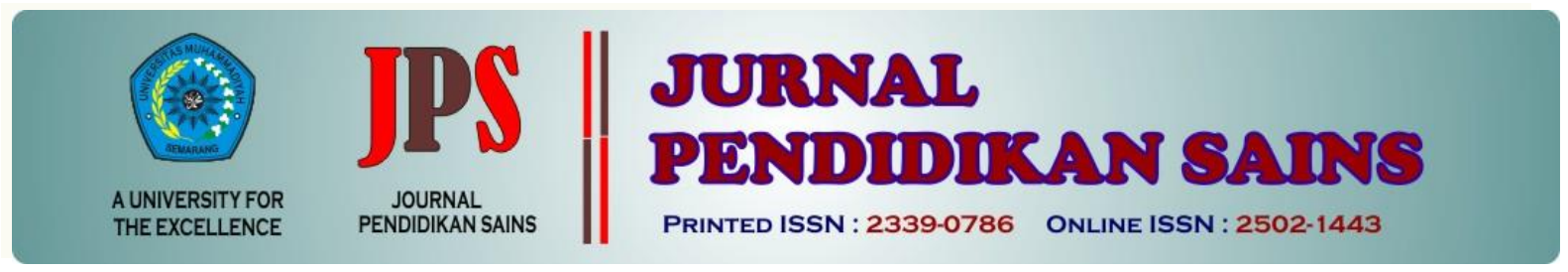

http://jurnal.unimus.ac.id/index.php/JPKIMIA

\title{
HUBUNGAN PENGETAHUAN TENTANG PENCEMARAN LINGKUNGAN DENGAN PERILAKU RAMAH LINGKUNGAN PADA SISWA SMA
}

\author{
Oleh: \\ Ajeng Putri Fitriani Pertiwi, Diana Vivanti Sigit, Ratna Komala \\ Pendidikan Biologi, Fakultas MIPA, \\ Universitas Negeri Jakarta
}

\begin{tabular}{ll}
\hline \multicolumn{2}{l}{ Article history } \\
\hline Submission & $: 2018-09-07$ \\
Revised & $: 2018-10-15$ \\
Accepted & $: 2018-10-16$
\end{tabular}

Keyword:

Environmental pollution, Knowledge, Proenvironmental behavior

\begin{abstract}
Pro-environmental behavior is behavior towards environment that are oriented to minimize the negative impacts of environmental damage. Knowledge about environmental pollution will lead to pro environmental behavior that is very necessary to maintain the quality of the environment. This study aims to determine the relationship of knowledge about envionmental pollution and pro environmental behaviors on high school students. This research was conducted at SMAN 54 Jakarta on May 2018. The method used is descriptive method with correlational study. Samples were taken with Simple Random Samping technique as many as 120 students. Prerequisite test showed that data was normal and homogeneous. Hypothesis tests used linear regression test and simple correlation. Based on data analysis can be conclude, there is a positive relationship between knowledge about environmental pollution and pro environmental behavior.
\end{abstract}

\section{Pendahuluan}

Pencemaran lingkungan menimbulkan berbagai permasalahan diantaranya kelangkaan air di berbagai daerah akibat sumber air yang tercemar limbah industri dan limbah rumah tangga, polusi udara di perkotaan akibat zat sisa pembakaran kendaraan bermotor yang semakin meningkat, timbulnya banjir akibat berkurangnya daerah resapan air dan sebagainya.

Pencemaran lingkungan yang telah menjadi masalah global harus diatasi agar tetap terjaga kelestariannya sampai generasi yang akan datang. Salah satu upaya yang dapat dilakukan untuk mengatasi permasalahan lingkungan tersebut adalah dengan menerapkan perilaku ramah lingkungan. Perilaku ramah lingkungan adalah suatu perilaku sadar yang dilakukan oleh manusia dengan meminimalisir dampak negatif terhadap lingkungan (Kollmuss dan Agyeman, 2002). Perilaku ramah lingkungan dapat ditingkatkan melalui jalur pendidikan. Pendidikan memiliki peran penting untuk menciptakan individu profesional yang dapat menjaga kelestarian lingkungan (Heyl, 2013).

Semua pihak wajib turut serta dalam mengatasi permasalahan lingkungan termasuk siswa. Siswa SMA memiliki pengetahuan

*Corresponding Author:

Nama : Ajeng Putri F.P

Lembaga : Universitas Negeri Jakarta

Email : ajengpfp@gmai.com 
tentang pencemaran lingkungan dari mata pelajaran Biologi. Pengetahuan tentang pencemaran lingkungan pada siswa akan menjadi dasar dalam berperilaku sehingga siswa akan terdorong untuk berperilaku ramah lingkungan. Seseorang yang memiliki pengetahuan tentang permasalahan lingkungan dan tindakan positif potensial mengenai lingkungan akan bertindak secara sadar dengan cara yang lebih ramah terhadap lingkungan (Gifford dan Nilson, 2014).

\section{Metode Penelitian}

Metode penelitian yang digunakan adalah metode deskriptif dengan studi korelasional. Penelitian dilaksanakan pada bulan Mei 2018 di SMA Negeri 54 Jakarta. Populasi target dalam penelitian ini ialah seluruh siswa SMAN 54 Jakarta tahun pelajaran 2017/2018. Populasi terjangkau adalah seluruh siswa kelas $\mathrm{X}$ MIPA. Sampel penelitian ini adalah 120 siswa kelas $\mathrm{X}$ MIPA yang dipilih dengan menggunakan teknik simple random sampling.

Pada penelitian ini terdapat dua variabel yang diteliti. Variabel bebas (X) adalah pengetahuan tentang pencemaran lingkungan yang diukur dengan menggunakan instrumen tes pengetahuan tentang pencemaran lingkungan yang terdiri atas 50 butir soal pilihan ganda. Variabel terikat (Y) adalah perilaku ramah lingkungan pada siswa SMA yang diukur dengan instrumen yang telah dimodifikasi dari alat ukur Pro Environmental Behavior Scale yang dikembangkan oleh Kaiser dan Bogner (2007).

\section{Hasil Penelitian dan Pembahasan}

Perolehan nilai pengetahuan tentang pencemaran lingkungan pada siswa SMAN 54 Jakarta dapat dilihat pada Tabel 1 .

Tabel 1. Nilai Pengetahuan Tentang Pencemaran Lingkungan pada Siswa

\begin{tabular}{ccc}
\hline Interval & $\begin{array}{c}\text { Frekuensi } \\
\text { Absolut }\end{array}$ & $\begin{array}{c}\text { Frekuensi } \\
\text { Relatif(\%) }\end{array}$ \\
\hline $49-54$ & 1 & 0,83 \\
$55-60$ & 0 & 0,00 \\
$61-66$ & 11 & 9,17 \\
$67-72$ & 26 & 21,67 \\
$73-78$ & 31 & 25,83 \\
$79-84$ & 38 & 3167
\end{tabular}

\begin{tabular}{ccc}
$85-90$ & 12 & 10,00 \\
$91-96$ & 1 & 0,83 \\
Jumlah & 120 & 100 \\
\hline
\end{tabular}

Siswa memiliki nilai pengetahuan tentang pencemaran lingkungan dengan kategori tinggi sebanyak 112 siswa $(93,3 \%)$. Kategori sedang didapat oleh masing-masing 8 siswa $(6,7 \%)$, Kategori pengetahuan tentang pencemaran lingkungan rendah dapat dilihat pada Tabel 2.

Tabel 2. Persentase Kategori Pengetahuan tentang Pencemaran Lingkungan pada Siswa

\begin{tabular}{cccc}
\hline $\begin{array}{c}\text { Persentase } \\
\text { nilai }(\%)\end{array}$ & Kategori & $\begin{array}{c}\text { Frekuensi } \\
\text { Absolut }\end{array}$ & $\begin{array}{c}\text { Frekuensi } \\
\text { Relatif }\end{array}$ \\
\hline $0-31$ & Rendah & 0 & \\
$32-65$ & Sedang & 8 & 6,7 \\
$66-100$ & Tinggi & 112 & 93,3 \\
\hline
\end{tabular}

Persentase ketercapaian dimensi pengetahuan dapat dilihat pada Tabel 3 . Dimensi pengetahuan faktual memiliki persentase paling tinggi yaitu sebesar $45 \%$. Dimensi dengan persentase terendah adalah dimensi pengetahuan prosedural sebesar 23,7\%. Sedangkan dimensi pengetahuan konseptual memiliki persentase sebesar 31,3\% Tabel 3. Persentase Nilai Pengetahuan tentang Pencemaran Lingkungan pada Siswa per Dimensi

\begin{tabular}{cc}
\hline Dimensi & Persentase Pengetahuan \\
\hline Faktual & 45 \\
Konseptual & 31,3 \\
Prosedural & 23,7 \\
\hline
\end{tabular}

Perolehan nilai perilaku ramah lingkungan pada siswa SMAN 54 Jakarta dapat dilihat pada Tabel 4

Tabel 4. Distribusi Nilai Perilaku Ramah Lingkungan.

\begin{tabular}{ccc}
\hline $\begin{array}{c}\text { Nilai Perilaku } \\
\text { Ramah } \\
\text { Lingkungan }\end{array}$ & $\begin{array}{c}\text { Frekuensi } \\
\text { Absolut }\end{array}$ & $\begin{array}{c}\text { Frekuensi Relatif } \\
(\%)\end{array}$ \\
\hline $43-47$ & 3 & 2,50 \\
$48-52$ & 10 & 8,33 \\
$53-57$ & 19 & 15,83 \\
$58-62$ & 29 & 24,17 \\
$63-67$ & 32 & 26,67 \\
$68-72$ & 17 & 14,17
\end{tabular}




\begin{tabular}{ccc}
$73-77$ & 8 & 6,67 \\
$78-82$ & 2 & 1,67 \\
Jumlah & 120 & 100 \\
\hline
\end{tabular}

Mayoritas siswa memiliki nilai perilaku ramah lingkungan dengan kategori positif yaitu sebanyak 80 siswa $(66,70 \%)$. Sedangkan 40 siswa $(33,30 \%)$ mendapat kategori negatif, seperti terlihat pada Tabel 3 .

Tabel 3. Persentase Kategori Nilai Perilaku

Ramah Lingkungan pada Siswa

\begin{tabular}{llc}
\hline Rentang Nilai & Kategori & Persentase (\%) \\
\hline $20-59$ & Negatif & 33,3 \\
$60-100$ & Positif & 66,7 \\
\hline
\end{tabular}

Nilai perilaku ramah lingkungan pada siswa yang diperoleh mencakup 6 dimensi. Dimensi perilaku ramah lingkungan yang memiliki persentase ketercapaian tertinggi adalah dimensi Energy Conservation sebesar 20\%. Sedangkan dimensi dengan persentase terendah adalah dimensi Transportation and Mobility sebesar 8,6\%. Perbandingan persentase tiap dimensi dapat dilihat pada Tabel 4.

Tabel 4. Persentase Nilai Perilaku Ramah Lingkungan pada Siswa per Dimensi

\begin{tabular}{ll}
\hline \multicolumn{1}{c}{ Dimensi } & Persentase (\%) \\
\hline Energy Conservation & 20 \\
Transportation and Mobility & 8,6 \\
Waste Avoidance & 18,5 \\
Consumerism & 18,9 \\
Recycling & 15,7 \\
Vicarious, Social Behavior & \\
toward Conservation & 18,3 \\
\hline
\end{tabular}

Mayoritas siswa telah memiliki pengetahuan tentang pencemaran lingkungan yang tinggi disebabkan oleh hasil dari proses pembelajaran tentang pencemaran lingkungan yang didapatkan siswa pada mata pelajaran biologi. Siswa juga mendapatkan pengetahuan tentang pencemaran lingkungan dari media elektronik dan media cetak yang banyak membahas tentang pencemaran lingkungan dan dampaknya. Hal tersebut sesuai dengan teori dari Notoadmodjo (2007) bahwa pengetahuan adalah hasil penginderaan manusia atau hasil tahu seseorang terhadap objek melalui indra yang dimilikinya (mata, hidung dan sebagainya). Pengetahuan dapat diperoleh dari berbagai sumber. Sebagian besar pengetahuan diperoleh melalui pendidikan, buku petunjuk, pengalaman, media elektronik, media massa dan lingkungan. Sumber pengetahuan juga berasal dari pemimpin-pemimpin masyarakat, ahli agama, pemegang pemerintahan dan sebagainya.

Berdasarkan perhitungan persentase ketercapaian dimensi pengetahuan tentang pencemaran lingkungan pada gambar 4, dimensi pengetahuan faktual memiliki persentase ketercapaian paling tinggi yaitu sebesar $45 \%$. Hal tersebut disebabkan karena pengetahuan faktual adalah dimensi pengetahuan yang paling mudah dimengerti oleh siswa karena pengetahuan faktual belum memerlukan kemampuan berpikir tingkat tinggi. Dalam pengetahuan faktual siswa diminta untuk memiliki kemampuan mengingat dan memahami suatu materi yang telah dipelajari sebelumnya. Hal ini sesuai dengan teori Anderson (2011) yang menjelaskan bahwa pengetahuan faktual adalah pengetahuan yang meliputi elemen dasar yang digunakan dalam menjelaskan, memahami dan secara sistematis menata suatu disiplin ilmu sehingga mudah dipahami siswa.

Pesentase ketercapaian dimensi pada Tabel 4 juga menunjukkan bahwa dimensi dengan persentase ketercapaian terendah adalah dimensi pengetahuan prosedural $(23,7 \%)$. Hal ini disebabkan karena pengetahuan prosedural membutuhkan kemampuan berpikir tingkat tinggi untuk menganalisis suatu permasalahan. Anderson (2011) menjelaskan bahwa pengetahuan prosedural merupakan pengetahuan tentang cara melakukan sesuatu dan berupa rangkaian langkah atau strategi dalam suatu proses pemecahan masalah pembelajaran. Selain itu, rendahnya ketercapaian dimensi pengetahuan prosedural pada siswa juga disebabkan karena siswa belum terbiasa mengembangkan cara berpikir untuk melihat berbagai kemungkinan dalam menganalisis dan memecahkan masalah suatu permasalahan lingkungan. Hamdani (2015) juga menjelaskan bahwa metode mengajar guru juga mempengaruhi hasil pengetahuan siswa. Guru masih menggunakan strategi pembelajaran yang berpusat pada 
pengajar, sementara siswa hanya sebagai pendengar saja. Akibatnya apa yang telah disampaikan pengajar hanya sedikit saja yang diingat.

Persentase dimensi perilaku ramah lingkungan pada Tabel 4 menunjukkan bahwa dimensi perilaku ramah lingkungan dengan persentase tertinggi adalah dimensi Energy Conservation yaitu sebesar 20\%. Hal tersebut disebabkan karena perilaku konservasi energi berupa usaha mengurangi konsumsi sumber energi serta dapat pula mulai menggunakan sumber energi terbarukan sangat mudah untuk diterapkan oleh siswa dalam kehidupan seharihari.

Dimensi perilaku ramah lingkungan dengan kategori paling rendah adalah dimensi Transportation and Mobility yaitu sebesar $8,6 \%$. Hal ini disebabkan karena siswa merasa penggunaan kendaraan bermotor sangat efisien karena lebih menghemat waktu dan memudahkan dalam berbagai mobilitas saat beraktifitas. Sesuai dengan penjelasan Oktaviastuti dan Wijaya (2017) yang menyatakan bahwa peningkatan mobilitas kegiatan menyebabkan seseorang membutuhkan alat trasportasi yang praktis dan cepat sehingga penggunaan kendaraan bermotor pun semakin meningkat.

Berdasarkan hasil penelitian, pengetahuan tentang pencemaran lingkungan dan perilaku ramah lingkungan memiliki hubungan yang positif dan signifikan. Hasil penelitian tersebut menunjukkan bahwa semakin tinggi pengetahuan tentang pencemaran lingkungan pada siswa SMA maka semakin tinggi pula perilaku ramah lingkungannya. Begitu pula sebaliknya, semakin rendah pengetahuan tentang pencemaran lingkungan, maka semakin rendah pula perilaku ramah lingkungannya. Manusia sebagai makhluk yang memiliki akal dan pemikiran akan mampu menerapkan pengetahuan untuk landasan berperilaku. Seseorang yang memiliki pengetahuan tentang faktor yang menyebabkan terjadinya pencemaran lingkungan akan menerapkan perilaku ramah lingkungan untuk meminimalisir terjadinya pencemaran lingkungan. Dalam berperilaku sehari-hari, seseorang akan lebih memperhatikan lingkungan seperti menggunakan produk ramah lingkungan, hemat energi, menggunakan transportasi umum, tidak membuang sampah dan limbah ke sungai dan melakukan daur ulang barang bekas. Hal ini sesuai dengan model perilaku ramah lingkungan yang menjelaskan bahwa pengetahuan tentang lingkungan adalah dasar seseorang untuk berperilaku ramah lingkungan. Seseorang yang memiliki pengetahuan tentang lingkungan akan terdorong untuk menerapkan perilaku ramah lingkungan (Kollmus dan Agyeman, 2002). Penelitian yang dilakukan oleh Robelia dan Murphy (2012) menyatakan bahwa pengetahuan yang tinggi tentang berbagai permasalahan lingkungan seperti sampah, penyebab kerusakan habitat, perubahan iklim, produksi energi dan kualitas air dapat menjadi prediktor untuk berperilaku ramah lingkungan. Menerapkan perilaku ramah lingkungan akan lebih sulit apabila seseorang memiliki pengetahuan tentang lingkungan yang salah atau bahkan tidak memiliki pengetahuan tentang lingkungan (Gifford dan Nilson, 2014).

Tabel 5. Hasil Uji Analisis Koefisien Korelasi

\begin{tabular}{llrr}
\hline & \multicolumn{3}{c}{$\begin{array}{c}\text { Pengetahuan_Tentang__ Perilaku_Ramah } \\
\text { Pencemaran_Lingkungan __ingkungan }\end{array}$} \\
\hline $\begin{array}{llrr}\text { Pengetahuan_Tentang_ } \\
\text { Pencemaran_Lingkungan }\end{array}$ & Pearson Correlation & 1 & $.290^{* *}$ \\
& Sig. (2-tailed) & 120 & .001 \\
& N & $.290^{* *}$ & 120 \\
Perilaku_Ramah_ & Pearson_Correlation & .001 & \\
Lingkungan & Sig. (2-tailed) & 120 & 120 \\
& N & & \\
\hline
\end{tabular}

Tabel 5 menunjukkan bahwa nilai koefisien korelasi pengetahuan tentang pencemaran lingkungan dengan perilaku ramah lingkungan yang didapatkan pada penelitian ini adalah 0,290 sehingga tergolong rendah. Nilai koefisien determinasi yang didapat adalah 0,84 yang berarti bahwa variabel pengetahuan tentang pencemaran lingkungan memberikan kontribusi hanya $8,4 \%$ terhadap variabel perilaku ramah lingkungan. Sedangkan 91,6\% lainnya dipengaruhi oleh faktor lain. Untuk dapat timbulnya suatu perilaku ramah lingkungan diperlukan berbagai rangsangan dari faktor internal atau dari dalam diri seseorang maupun faktor eksternal atau lingkungan. Hal ini sesuai 
dengan penelitian Krajhanzl (2010) yang menyebutkan bahwa ada tiga faktor yang mempengaruhi perilaku ramah lingkungan, yaitu: faktor yang timbul dari kondisi lingkungan, faktor kepribadian individu, dan faktor hubungan pribadi individu dengan alam.

\section{Simpulan dan Saran}

Simpulan

Berdasarkan hasil penelitian dapat disimpulkan bahwa terdapat hubungan positif antara perilaku ramah lingkungan dengan perilaku ramah lingkungan pada siswa SMAN 54 Jakarta.

Saran

Hasil dari penelitian ini dapat digunakan sebagai acuan tentang pentingnya pengetahuan tentang pencemaran lingkungan dalam meningkatkan perilaku ramah lingkungan. Sekolah dan guru dapat meningkatkan lagi kualitas pembelajaran di sekolah dan tidak hanya menekankan pada teori tetapi juga penerapan pengetahuan dalam kehidupan sehari-hari yang tercermin dari perilaku sehingga diharapkan pengetahuan tentang pencemaran lingkungan dan perilaku ramah lingkungan pada siswa dapat meningkat.

\section{Daftar Pustaka}

Anderson, LW, dan Krathwohl. (2010). Kerangka Landasan untuk Pembelajaran, Pengajaran, dan Asesmen, A. Yogyakarta : Pustaka Pelajar.

Gifford, R. dan Nilson, A. 2014. Personal and Social Factors that Influence Proenvironmental Concern and Behavior: A Review. International Journal of Psychology. 49 (3). 2-11.

Hamdani. 2015. Meningkatkan Pengetahuan Konseptual Dan Pengetahuan Prosedural Mahasiswa Melalui Pendekatan Diskursus Matematik. Jurnal
Pendidikan Matematika dan IPA. 6 (1). 13-25.

Heyl,M., Diazy, M.E, dan Cifuentes, L. Environmental Attitudes and Behaviour College Students: A Case Study Conducted At A Chilean University. Revista Latinoamericana de Psicologia. 45 (3). 489-502.

Kaiser, F.G., Hubner, G. dan Bogner, F. X. 2005. Contrasting The Theory of Planned Behavior with the Value-BeliefNorm Model in Explaining Conservation Behavior. Journal of Applied Social Psychology. 35 (10).

Kollmuss, A. dan Agyeman, J. 2002. Mind the Gap: Why Do People Act Environmentally and What are the Barriers to Pro-environmental Behavior ?. Journal of Environmental Education Research. 8 (3). 240-257.

Krajhanzl, J. 2010. Environmental and Proenvironmental Behavior. Journal of Health Education International Experiences. 4 (21).

Notoatmodjo, S. 2007. Pendidikan dan Perilaku Kesehatan. Jakarta: Rineka Cipta.

Oktaviastuti, B dan Wijaya, H. Urgensi pengendalian kendaraan bermotor $\mathrm{Di}$ indonesia. Jurnal Rekayasa Teknis Sipil Unversitas Madura. 2 (1). 5-8. 